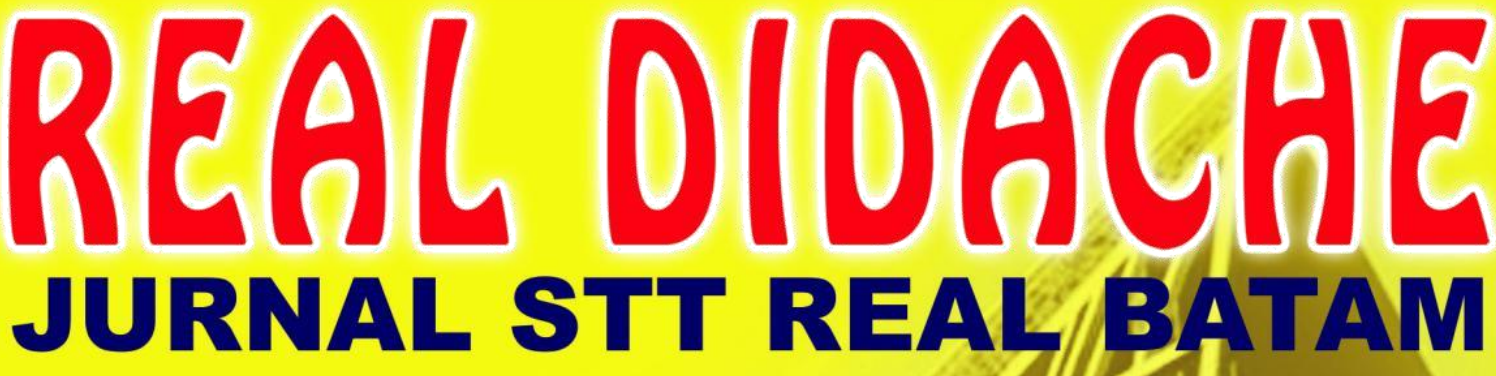

ALLAH MERANCANG KELUARGA (Kej. 1:27-28) SEBUAH TEOLOGI KELUARGA

Eko Prasetyo

ISLAM INDONESIA: SEBUAH OVERVHEW DAN PENDEKATAN MISI

Irfan Feriando Simanjuhtak

KONSEP KURIKULUM PEMBINAAN WARGA

GEREJA KHUSUSNYA BA GI REMAJA

Rita Evimalinda

PENDIDIKAN AGAMA KRISTEY GEREJA DAAN

KETELADANAN ORANG TUA TERHĀDAP

PEMBENTUKAN KARAKTER ANAK SEKOLAH MINGGU

Ester Lina Situmorang

PENYELENGGARAAN PENDIDIKAN/AGAMA KRISTEN

BERDASARKAN PERILAKU PENDIDIK, BAHAN AJAR

DAN METODE BELAJAR PEMBELAJARANTERHADAP

UPAYA REVITALISASI DAN PENINGKATANMUTU

Manahan Uji Simanjuntak

POLA ASUH ORANGTUA YANG EFEIKTIF PADA

PERKEMBANGAN PSIKOLOGI ANAK USIA DINI

Luhut ElRoy Manalu

STRATEGI PENDIDIKAN AGAMA KRISTEN

DALAM PEMBENTUKAN PERILAKU ANAK

Daniel Agüstin Sihombing

ril $\mid 1 / \pi \rightarrow 11$

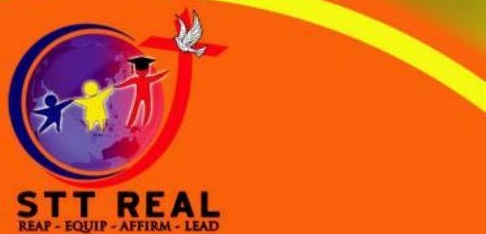




\title{
ISLAM INDONESIA SEBUAH OVERVIEW DAN PENDEKATAN MISI
}

\author{
Oleh: Irfan F. Simanjuntak
}

\begin{abstract}
Abstraksi: Islam adalah agama dengan penganut terbesar kedua di dunia. Di Indonesia, ia menempati posisi pertama dengan $88,2 \%$ penganut sehingga menempatkan Indonesia sebagai negara dengan populasi Muslim terbesar di dunia. Didirikan oleh Muhammad yang menerima wahyu dan menuliskannya dalam Al Quran, Islam menjadi agama yang mengklaim sebagai paling akhir dan sempurna. Di Indonesia kedatangannya terjadi secara damai, dibawa oleh para pedagang yang akhirnya mengubah wajah kepulauan nusantara menjadi negara mayoritas Muslim. Tidak dapat dipungkiri, selain sumbangsih para pedagang tersebut, ada tokoh-tokoh yang disebut Wali Songo yang menjadi sokoguru perkembangan Islam di nusantara. Sekalipun kesahihan historis tokoh-tokoh ini diragukan, sampai sekarang mayoritas orang Islam Indonesia masih meyakini keberadaan dan kontribusi mereka. Dengan berkembangnya agama ini di Indoensia, karakteristik Islam di Indonesia, sekalipun memiliki keserupaan dengan negara-negara lain, tetap memiliki keunikannya tersendiri. Dalam kalangan Islam umumnya dikenal ada dua kelompok, yakni abangan dan santri yang masing-masing menghayati agamanya dengan cara yang sedikit berbeda. Namun terlepas dari itu semua, hal yang perlu diperhatikan adalah bahwa mereka adalah ladang misi yang harus didekati dengan kasih melalui dialog.
\end{abstract}

Kata-kata Kunci: Islam, Muslim, pendekatan, kasih 


\section{PENDAHULUAN}

Islam adalah agama terbesar kedua di dunia setelah kekristenan. Agama ini didirikan oleh Muhammad di awal-awal abad ketujuh dan telah menyebar ke berbagai penjuru dunia. Pada tahun 2000, ada sekitar 1,1 milyar orang Muslim di dunia dan menempati angka 19,6 \% dari jumlah populasi dunia.1 Pertumbuhan agama ini juga sangat signifikan. Rata-ratanya mencapai 2,3 \% pada tahun 2001.2 Ini berarti, jika angka pertumbuhan ini tetap bertahan, maka pada tahun 2025, akan ada sekitar 1,7 milyar orang Islam di dunia atau 28 \% dari populasi dunia.з Angka-angka ini menunjukkan Islam adalah sebuah agama yang sangat berkembang.

Islam adalah agama yang memiliki akar yang sama dengan Kekristenan dan Yudaisme, dalam hal kitab suci dan juga nabi-nabi yang dipercayai. Mereka juga memiliki beberapa keyakinan yang berarsiran dengan agama Kristen sekalipun mereka memberikan klaim bahwa agama merekalah yang paling utama dan puncak. Oleh karena itu, adalah penting untuk menyelidiki dan memahami keyakinan-keyakinan agama ini. Inilah yang merupakan tujuan dari karya tulis ini, yaitu untuk meneliti keyakinan-keyakinan dasar agama Islam dan membandingkannya dengan keyakinan Kristen dalam

rangka untuk mencari titik kontak/temu untuk mendekati

1David A. Barrett, World Christian Encyclopedia (Nairobi: Oxford University Press, 2001), 4.

2http://www.bible.ca/islam/islam-myths-fastest-growing.htm.

(Diakses 24 Agustus 2017).

3Barrett, World Christian Encyclopedia, 4. 
mereka.

Dalam rangka mencapai tujuan tersebut, karya tulis ini akan menjelaskan sejarah agama Islam, keyakinankeyakinannya--tentu saja dengan penyingkatanpenyingkatan karena keterbatasan ruang yang tersedia dalam karya tulis ini dan luasnya keyakinan agama Islam, dan situasi terkini agama Islam terutama di Indoenesia. Hal ini dilakukan karena pemahaman yang benar terhadap mereka akan membuka kesempatan bagi kita untuk melakukan pendekatan terhadap mereka. Lebih lagi, Indonesia sebagai negara dengan populasi Muslim terbesar di dunia -- 88,2 \% dari 250 juta penduduknya,4 adalah ladang misi yang cukup luas yang perlu mendapat perhatian serius. Melalui pendekatan misiologikal yang akan diuraikan tersebut, diharapan karya tulisan ini mencapai tujuannya.

\section{ISLAM DAN INDONESIA}

Sebelum kita membahas Islam di Indonesia, berikut ini akan terlebih dahulu dibahas tentang sejarah agama Islam dan keyakinan-keyakinannya. Hal ini dilakukan agar kita memiliki dasar yang benar untuk mengenal agama tersebut.

4"Indonesia." International Religious Freedom Report 2006. United States Department of State. http://www.state.gov/g/dr//rls/ irf/2006/71341.htm. (Diakses 24 August 2017). 


\section{Sejarah Singkat dan Keyakinan Agama Islam}

Islam berasal dari Arab dan didirikan oleh Muhammad, yang dipercaya oleh orang Islam sebagai nabi terakhir dan terbesar. Meskipun biografi standar orang Muslim tentang Muhammad disusun lebih dari seratus tahun sesudah kematiannya -- disunting pada abad kesembilan Masehi,5dan telah membangkitkan banyak perdebatan dan penelitian lanjutan tentang historisitas sejarah kehidupan Muhammad, kelihatannya adalah lebih baik jika bagian ini disusun berdasarkan keyakinan tradisional orang Muslim tentang kehidupan Muhammad tersebut karena seperti yang telah diuraikan di bagian pendahuluan, tujuan utama karya tulis ini bukanlah untuk memperdebatkan dan membicarakan secara luas keaslian kisah hidup Muhammad.

Menurut kisah tradisional yang dipercaya orang Muslim, Muhammad lahir sekitar tahun $570 \mathrm{M}$ dan berasal dari keluarga Kusai.6 Dia menerima wahyu pertamanya di bukit Hira ketika berusia 40 tahun dan sepanjang sisa hidupnya dihabiskannya untuk menerima sekaligus mengajarkan wahyu yang ia terima tersebut.7 Kisah hidupnya dengan baik disimpulkan oleh Baldick sebagai berikut:

Seorang anak yatim piatu, dia telah menjadi pedagang, menerima wahyu-wahyu, menerima pengikut, dianiaya, melarikan diri ke Medina, sekitar kurang lebih dua

5Julian Baldick, "Early Islam," dalam The World's Religions, ed.

Steward Sutherland (London: Routeledge, 1988), 314-315.

${ }_{6}$ David A. Brown, A Guide to Religions (Delhi: ISPCK, 1991), 184.

7Salman Hakim, History of Islam. http://www.mnsu.edu/

emuseum/cultural/religion/islam/history.html. (Diakses 24 Agustus 2017). 
ratus mil ke utara, membentuk persekutuan antara orang Arab dan Yahudi yang ada di situ, terlibat dalam pertempuran-pertempuran lokal, menaklukkan Mekah, dan mati pada tahun 632 di Medina.8

Dengan demikian, Muhammad menghabiskan waktu sekitar 22 tahun untuk menyebarkan ajarannya sebelum ia meninggal dunia. Namun, apa yang ia telah tanam tersebut terus bertumbuh, bahkan lama setelah tahun kematiannya. Dan saat ini, agama yang didirikan oleh Muhammad tersebut tidak hanya berkembang di jazirah Arab saja, tetapi telah tersebar ke hampir seluruh penjuru dunia.

Berkaitan dengan pengertian nama Islam, ungkapan Rahman dalam Encyclopedia of Religion perlu diperhatikan. Menurut Rahman, "nama Islam berakar dari bentuk slm dalam bahasa Arab yang berarti 'berada dalam damai atau menjadi utuh'; dari akar kata ini muncullah istilah Islam, yang berarti 'tunduk atau berserah kepada hukum-hukum Allah dan karena itu berada dalam keadaan yang utuh' dan Muslim, seseorang yang sangat berserah."” Orang-orang Muslim percaya bahwa Islam adalah agama Allah yang kekal. Hal ini dinyatakan dalam Al Quran sebagai "sifat awal yang dimiliki saat Allah menciptakan manusia" (30:30), bahkan istilah muslim diklaim sebagai kata yang dicetuskan oleh Abraham sendiri (22:78).10

Keyakinan-keyakinan Islam berdasarkan pada AI Quran. Al Quran dipercaya sebagai firman Allah yang diwahyukan

8Baldick, Early Islam, 315.

9Fazhur Rahman, "Islam: An Overview (First Edition)" dalam Encyclopedia of Religion 2nd ed, ed. Lindsay Jones, vol. 7 (Detroit: Thomson Gale, 2005), 4560.

10Rahman, Islam: An Overview, 4561. 
kata demi kata, yang dinyatakan kepada Muhammad melalui malaikat yang bernama Jibril. Bagi orang Muslim, Al Quran adalah, demikian Nasr "firman Allah yang sejati yang diwahyukan kepada utusan-Nya sama seperti Kristus bagi orang Kristen, yang adalah firman Allah yang datang ke dunia melalui Perawan Maria." ${ }_{11}$ Orang Muslim juga melihat Hadis dan Sunah sebagai otoritas iman mereka disamping Al Quran. Hadis adalah tradisi yang diturunalihkan dari 'temanteman dekat sang Nabi' sementara Sunah adalah praktek kebiasaan sang Nabi.12 Semua hal tersebut menjadi otoritas dalam membentuk kehidupan, keyakinan dan kebiasaan orang-orang Muslim.

Orang-orang Muslim juga harus menegakkan Lima Pilar Iman melalui kehidupan mereka. Lima Pilar Iman ini menjadi dasar dalam kehidupan beriman mereka. Lima Pilar tersebut adalah: Deklarasi Iman Islam (Syahadat), Sembahyang lima waktu sehari (Sholat), pemberian sedekah (Zakat), menahan lapar sebulan penuh sepanjang bulan Ramadhan (Puasa), dan ziarah ke Mekah (Haji). Orang Muslim juga percaya 6 hal yang berkaitan dengan dasar iman mereka. Mereka percaya kepada Allah yang Esa, malaikat, kitab suci, nabi-nabi, hari penghakiman dan takdir. Meskipun orang Muslim diberbagai belahan dunia memiliki ciri kehidupan yang berbeda-beda, dapat dikatakan bahwa dalam hal-hal dasar ini mereka sama.

${ }_{11}$ Seyyed Hossein Nasr, "The Quran as the Foundation of Islamic Spirituality," dalam Islamic Spirituality: Foundations, ed. Seyyed Hossein Nasr (New York: Crossroad, 1987), 4.

${ }_{12}$ Peter Clarke, "Islam: Introduction," dalam The World's

Religions, ed. Steward Sutherland (London: Routeledge, 1988), 309. 


\section{Islam di Indonesia}

Ada berbagai pendapat tentang awal datangnya agama Islam ke Indonesia. Geertz mengatakan "Orang Muslim India yang bertindak sebagai pedaganglah yang pertama kali menyebarkan agama Islam di Indonesia di abad kedelapan dan kesembilan Masehi." 13 Beberapa penulis Indonesia, demikian Johns, "telah berusaha untuk membuktikan bahwa yang pertama datang menyebarkan agama Islam adalah orang Arab yang datangnya ke Indonesia di sekitar abad kedelapan." ${ }_{14}$ Kratz meneguhkan hal ini dengan mengutip kesimpulan para sarjana dan teolog Muslim Indonesia yang diformulasi pada tahun 1963 yang berkumpul untuk mendiskusikan sejarah awal Islam di Indonesia, mengatakan "agam Islam memasuki Indonesia untuk pertama kalinya diantara abad ketujuh dan kedelapan Masehi dan datang secara langsung dari Arab." ${ }_{15}$ Kepelbagaian pendapat ini terjadi karena, demikian Kratz, "sedikitnya fakta sejarah yang tersedia, bukti-bukti efigrafis dan material lainnya sangat jarang dijumpai dan berbicara tentang tahun-tahun yang lebih kemudian saja sehingga sejarah paling awal dari Islam di Indonesia tetaplah kabur sebagaimana yang diajarkan juga oleh para sarjana Barat." ${ }_{16}$ Bukti arkeologis terawal adalah "sebuah kuburan yang

${ }_{13}$ Clifford Geertz, The Religion of Java (Chicago: University of Chicago Press, 1976), 124.

${ }_{14} \mathrm{~A}$. H. Johns, "Islam: Islam in Southeast Asia," in Encyclopedia of Religion 2 nd ed., ed. Lindsay Jones, vol. 7 (Detroit: Thomson Gale, 2005), 4658.

${ }_{15} \mathrm{E}$. U. Kratz, "Islam in Indonesia," dalam The World's Religions, ed. Steward Sutherland (London: Routeledge, 1988), 432.

${ }_{16} \mathrm{Kratz}$, Islam in Indonesia, 431- 32. 
tahunnya diperkirakan mendekati angka $1082 \mathrm{M}$, yang mengacu kepada kuburan seorang anak perempuan seorang pedagang di Leren di pesisir utara Jawa." ${ }_{17}$ Oleh karena itu, kesimpulan pasti yang bisa diambil adalah bahwa agama Islam datang ke Indonesia sebelum abad kesebelas. Hal ini, tentu saja, didasarkan pada asumsi bahwa agama Islam telah datang sebelum bukti arkeologis itu ada.

\section{Proses Islamisasi}

Di Indonesia, telah dipahami secara umum bahwa agama Islam datang dengan cara yang damai dan kedatangannya ke Nusantara dibawa oleh para pedagang dalam proses yang lambat. Karena Indonesia adalah negara kepulauan, maka harus dipahami bahwa kedatangan agama Islam ke Indonesia tidaklah sama di setiap wilayah. Oleh karena itu, penjelasan berikut akan dibatasi hanya pada tempat-tempat yang memainkan peran penting dalam proses islamisasi Indonesia.

Aceh menempati peran penting bagi perkembangan agama Islam karena di awal-awal masuknya agama Islam di Indonesia, Aceh merupakan salah satu pintu masuknya. Peran Aceh terhadap perkembangan awal Islam di Indonesia dengan baik dijelaskan oleh Johns:

Para peziarah dan sarjana yang sangat bersemangat dari seluruh kepulauan akan melakukan perjalanan

17Johns, Islam: Islam in Southeast Asia, 4659. 
secara bertahap selama beberapa tahun. Aceh adalah pelabuhan dan tempat persinggahan terakhir serta tempat belajar terakhir yang mereka akan temukan sebelum mereka meninggalkan wilayah mereka sendiri... Aceh juga merupakan tempat pertama yang mereka datangi setelah mereka pulang dari perjalanan tersebut. 18

Aceh juga memainkan peran penting karena, demikian Kratz, "semua orang Muslim yang pergi menunaikan haji akan mengambil rute via pelabuhan Aceh. " ${ }_{19} \mathrm{Hal}$ inilah yang menjadi alasan mengapa Aceh disebut sebagai Negeri Serambi Mekah.

Di Jawa, negara/kerajaan pertama yang menjadi Islam adalah Demak, yang "muncul di tahun 1518 di pesisir utara pulau Jawa." 20 Wali songo (sembilan wali) juga memainkan peranan yang penting dalam pemberitaan agama Islam dan penyebarannya. Menurut tradisi yang dipercayai, ada sembilan tokoh penting yang secara bersama-sama begitu bertanggungjawab dan berjasa dalam penyebaran agama Islam. "Dikenal sebagai Wali Songo, mereka dipahami di masa kini sebagai sangat berpengaruh dalam mentransformasi budaya dan agama orang Jawa." 21 Namun keotentikan sejarah tokoh-tokoh tersebut memiliki sangat sedikit bukti nyata. Menurut Johns, "angka sembilan bisa jadi lebih mengandung simbolisme kosmologi daripada arti aritmatik, sejak sembilan tokoh tersebut mengacu kepada tujuh arah

18Johns, Islam: Islam in Southeast Asia, 4661.

${ }_{19} \mathrm{Kratz}$, Islam in Indonesia, 437.

${ }_{20} \mathrm{Kratz}$, Islam in Indonesia, 434.

21http://www.eastjava.com/books/walisongo/html/intro.html

(Diakses 30 Agustus 2017). 
mata angin dengan satu pusatnya." 22 Lagi pula, "hanya dari akhir abad keenambelas saja kita mampu mengidentifikasi pribadi-pribadi pemimpin agama, mendapatkan akses kepada hasil karya yang mereka tulis." 23

Sebagai kesimpulan, proses awal terjadinya islamisasi di Indonesia terjadi dengan cara yang damai. Hal ini dapat dilihat dari tempat-tempat dimana agama Islam pertama kali masuk; agama Islam masuk ke bagian-bagian pesisir pantai. Jika hal ini benar maka tradisi yang mengatakan agama Islam dibawa oleh para pedagang dapat diterima.

\section{Karakteristik Islam}

Islam di Indonesia umumnya dilihat sebagai dua kelompok; santri dan abangan. Abangan adalah para penganut agama nominal sedangkan Santri merupakan mereka yang secara ketat mempraktekkan ritual dan hukum-hukum Islam. Mereka dikategorikan sebagai Muslim 'orthodox' dan, demikian Kratz, "masih menganut konotasi bahwa mereka adalah pria dan wanita yang menarik diri mereka dari dunia ini dalam rangka menghabiskan waktu mereka dalam pembaktian di pesantren, tempat para santri." 24 Meskipun pengelompokan ini tidak terlalu tepat untuk diterapkan bagi orang-orang Islam di Indonesia pada masa kini, hal tersebut masih bisa

22Johns, Islam: Islam in Southeast Asia, 4662.

23Johns, Islam: Islam in Southeast Asia, 4662.

${ }_{24} \mathrm{Kratz}$, Islam in Indonesia, 443. 
menjelaskan karakteristik orang Islam di Indonesia. Geertz tampaknya memiliki peran yang penting dalam memberikan pengelompokan ini. Dalam bukunya, The Religion of Java, ia membedakan kelompok-kelompok ke dalam "Abangan; menekankan pada sekelompok orang Islam yang animistik yang masih lebih kuat keyakinan Jawanya, santri; menekankan sinkretisme yang lebih kuat aspek Islamnya, dan priyayi, menekankan aspek Hinduistik yang lebih kuat." 25

Di dalam kalangan santri sendiri, ada dua sub-grup lagi yang hidup saling berdampingan di Indonesia. Tanja menjelaskan dengan baik:

Yang pertama adalah apa yang orang biasa panggil tradisionalis. Para santri Muslim ini adalah penjaga pandangan-pandangan tradisional para ulama atau para sarjana agama dalam menafsirkan dan memahami teks-teks Quran dan Hadist. Yang kedua adalah kelompok modernis. Para santri Muslim ini adalah mereka yang akrab dengan pengajaran Muhammad Abduh, seorang reformer Islam dari Mesir, yang mendorong penggunaan pemikiran individual dalam usaha menafsirkan dan memahami teks-teks Quran dan Hadist, tanpa harus bergantung pada pendapat para ulama. 26

Oleh karena itu, secara mendasar dapat disimpulkan bahwa tidak terlalu mudah untuk membeda-bedakan Islam di Indonesia karena memang terdiri dari beberapa macam.

Fakta yang bisa disebutkan adalah, mayoritas orang Islam di Indonesia tergolong sebagai orang Islam moderat yang secara

${ }_{25}$ Geertz, The Religion of Java, 6.

${ }_{26}$ Victor Tanja, "Islamic Resurgence in Indonesia and

Christian Response," Asia Journal of Theology 5, no. 2 (1991), 361. 
teguh memegang ideologi dan falsafah bangsa, Pancasila 27 yang menjamin kebebasan mempraktekkan agama-agama yang diakui di Indonesia, seperti Islam, Kristen, Hindu dan Buddha.

\section{Menuju Pendekatan Misiologis}

Keyakinan-keyakinan Islam, dalam kadar tertentu, sangat dekat dengan kekristenan, meskipun tentu saja banyak juga perbedaannya. Dalam kepercayaan mereka tentang Allah, mereka meyakini monotheisme tulen dan tidak memberi tempat pada polytheisme dalam bentuk apapun. Orang Islam percaya, demikian Nasr, "doktrin Al Quran tentang Allah menyatakan Dia sebagai yang absolut, tak terbatas, sempurna sekaligus, merupakan sumber dari semua realitas dan semua kualitas positif yang termanifestasi dalam keteraturan alam semesta." 28 Ini berarti, dalam kadar tertentu, doktrin mereka tentang Allah relatif sama dengan keyakinan Kristen. Mereka juga percaya kepada Yesus, meskipun mereka tidak menerima-Nya sebagai Tuhan, melainkan sebagai nabi. Bahkan, Al Quran juga membicarakan tentang Taurat dan Injil sebagai firman Allah. Kesamaan-kesamaan ini, tentu saja, bisa menjadi pintu pembuka bagi sebuah dialog yang bersahabat

270hnstone Patrick, Operation World: The Day-by-Day Guide to Praying for the World (Grand Rapids, MI: Zondervan Publishing House, 1993), 292.

${ }_{28}$ Nasr, "God," dalam Islamic Spirituality: Foundations, 311. 
dengan mereka karena kita memiliki akar yang sama.

Namun walaupun demikian, agama Islam tentu saja berbeda dengan kekristenan. Dalam kepercayaan mereka tentang eskatologi, mereka percaya bahwa Allah akan menghakimi dunia dan di hari itu, "perbuatan mereka akan diukur di dalam sebuah timnbangan, barangsiapa yang melewati test tersebut akan diijinkan untuk masuk ke surga; barangsiapa yang gagal akan dibuang ke neraka (18:49; 17:13-15)." ${ }_{29}$ Keyakinan ini membawa kita kepada pemahaman bahwa keselamatan dalam Islam sangat bergantung pada perbuatan masing-masing individu. Tujuan keselamatan dalam Islam adalah fitrah, "kondisi manusia seharusnya yang daripadanya manusia sudah jatuh" ${ }_{30}$ Karena itu, fokus mereka adalah kembali kepada awalnya. Dan jalan untuk mencapainya, demikian Eaton, "terletak bukan pada pengharapan yang difokuskan pada tujuan yang jauh sekali atau melalui berbagai bentuk penebusan adikodrati dari kehidupan yang berdosa melainkan melalui pembersihan diri dari akresi dan distorsi yang telah merusak dan menghancurkan kesempurnaan yang merupakan sifat alami manusia." ${ }_{31}$ Kepercayaan ini tentunya sangat berbeda dengan iman Kristen yang mengajarkan bahwa keselamatan hanya terjadi karena karya anugerah dari Allah.

29Brown, A Guide to Religions, 209.

${ }_{30}$ Charles Le Gai Eaton, "Man," dalam Islamic Spirituality:

Foundations, 366.

${ }_{31}$ Eaton, Man, 366. 
Dengan demikian, orang Muslim di Indonesia harus dilihat sebagai ladang misi bagi kita. Namun haruslah diingat, di Indonesia pendekatan yang digunakan haruslah menghormati nilai-nilai harmoni dan kesatuan yang dijamin oleh negara. Kita harus mengedepankan kasih dalam pendekatan kita karena, menurut Tanja, "ide dasar dalam iman Kristen adalah kasih dan kasih berarti secara sukarela dan spontan mencari dan memahami identitas dan kepentingan orang lain dengan memberikan diri kita bagi orang lain tersebut. "32 Itu artinya, dialog bisa jadi merupakan jalan terpantas yang kita pilih untuk mendekati orang-orang Muslim. Berdasarkan karakteristik orang Muslim di Indonesia, kita tentunya bisa menggunakan berbagai pendekatan yang sangat bergantung dengan orang yang kita dekati. Pada dasarnya, upaya kita harus dilandaskan pada kasih yang dapat terlihat melalui sikap kita sebagai orang Kristen. Melalui cara ini, diharapkan kita dapat melakukan pendekatan kepada mereka dan dapat memberitakan Injil secara efektif kepada mereka.

\section{KESIMPULAN}

Islam di Indonesia memiliki karakteristiknya sendiri meskipun tentu saja ia juga memiliki kesamaan dengan Islam di berbagai belahan dunia ini. Kedatangannya yang

з2anja, Islamic Resurgence in Indonesia and

Christian Response, 364. 
melalui cara damai dan penerimaannya terhadap beberapa praktek kepercayaan yang lebih awal dari kebiasaan orang Indonesia telah membuat agama Islam begitu mengakar ke dalam sanubari orang Indonesia. Kesuksesan mereka dalam mengislamkan orang Indonesia dapat dilihat dari persentase penganut agama Islam di negara ini, yang menyebabkan Indonesia menjadi negara dengan penganut Muslim terbesar di dunia.

Persentase yang besar dari orang Muslim di Indonesia telah menyebabkan Indonesia menjadi sebuah ladang misi yang sangat besar yang kita sebagai orang Kristen ditantang untuk memberitakan Injil kepada mereka. Pendekatan kita terhadap mereka harus mendapatkan perhatian yang serius. Karena Indonesia adalah sebuah negara yang menjamin harmonisasi dalam setiap praktek kehidupan beragama, pendekatan dengan dialog menjadi cara terpantas untuk ditempuh. Kesaksian kita haruslah berlandaskan kasih; kasih yang diterapkan melalui kata dan perbuatan. Meskipun orang Muslim percaya bahwa agama mereka adalah agama tersempurna, kita harus membangun dialog dengan mereka dengan mana kita bisa bersaksi bahwa Yesuslah sang Juruselamat dan hanya melalui Dia dan di dalam Dia-lah manusia dapat diselamatkan. Usaha manusia, sebagaimana yang diajarkan dalam keyakinan Islam, tidak akan memberikan keselamatan. Inilah yang diungkapkan Alkitab ketika mengatakan bahwa kita diselamatkan karena kasih karunia 
oleh iman, bukan karena usaha dan perbuatan kita, sehingga tidak ada yang boleh memegahkan diri karenanya (bnd. Ef. 2:8-9). Oleh karena itu, adalah tugas kita untuk memberitakan kebenaran ini sehingga banyak orang yang akan datang dan percaya kepada Yesus. 


\section{DAFTAR PUSTAKA}

Baldick, Julian. "Early Islam." Dalam The World's Religions. Edited by Steward Sutherland. London: Routeledge, 1988.

Barrett, David A. World Christian Encyclopedia. Nairobi: Oxford University Press, 2001.

Brown, David A. A Guide to Religions. Delhi: ISPCK, 1991.

Clarke, Peter. "Islam: Introduction." Dalam The World's Religions. Edited by Steward Sutherland. London: Routeledge, 1988.

Eaton, Charles Le Gai. "Man.” Dalam Islamic Spirituality: Foundations, Edited by Seyyed Hossein Nasr. New York: Crossroad, 1987.

Geertz, Clifford. The Religion of Java. Chicago: University of Chicago Press, 1976.

Hakim, Salman. History of Islam. http://www.mnsu.edu/ emuseum/cultural/religion/islam/history.html.

http://www.eastjava.com/books/walisongo/html/intro.html.

http://www.bible.ca/islam/islam-myths-fastest-growing.htm.

Indonesia." International Religious Freedom Report 2006. United States Department of State. http://www.state. gov/g/drl/rls/irf/2006/71341.htm.

Johns, A. H. "Islam: Islam in Southeast Asia." Dalam Encyclopedia of Religion 2nd edition. Edited by Lindsay Jones, vol. 7. Detroit: Thomson Gale, 2005.

Kratz, E. U. "Islam in Indonesia." Dalam The World's Religions. Edited by Steward Sutherland. London: 
Routeledge, 1988.

Nasr, Seyyed Hossein. "The Quran as the Foundation of Islamic Spirituality." Dalam Islamic Spirituality: Foundations. Edited by Seyyed Hossein Nasr. New York: Crossroad, 1987.

Patrick, Johnstone. Operation World: The Day-by-Day Guide to Praying for the World. Grand Rapids, MI: Zondervan Publishing House, 1993.

Rahman, Fazhur. "Islam: An Overview (First Edition)."

Dalam Encyclopedia of Religion 2nd edition. Edited by Lindsay Jones, vol. 7. Detroit: Thomson Gale, 2005.

Tanja, Victor. "Islamic Resurgence in Indonesia and Christian Response." Asia Journal of Theology 5, no. 2 (1991): 359-365.

\section{TENTANG PENULIS}

Irfan F. Simanjuntak adalah dosen tetap di STT Real Batam. Saat ini mengepalai Departemen R \& D (Research and Development) di STT tersebut. 